\title{
Opłaty za postój pojazdów samochodowych na drogach publicznych - analiza prawna wybranych orzeczeń
}

\section{Parking fees for layover of motor vehicles on public roads - legal analysis of selected issues}

Streszczenie. W artykule poddano analizie opłatę za postój w strefie płatnego parkowania oraz wprowadzoną we wrześniu 2019 r. opłatę za postój w śródmiejskiej strefie płatnego parkowania. Część pierwsza opracowania dotyczy analizy prawnej tych opłat, sposobu ich nakładania oraz zawiera rozważania nt. stosowania do tych opłat Ordynacji podatkowej.

Słowa kluczowe: strefa płatnego parkowania (SPP); śródmiejska strefa płatnego parkowania (ŚSPP); opłata lokalna.

Abstract. The purpose of this article is to analyse fess for a paid parking zone and for a downtown paid parking zone (the second of the above-mentioned fees has been introduced in September 2019). First part of the paper provides a legal 
analysis of these fees and methods of imposing them. It also contains some reflections about an application and non-application of Tax Ordinance Act to these local fees.

Keywords: paid parking zone (PPZ); downtown paid parking zone (DPPZ); local fee.

\section{Zagadnienia wstępne}

Opłaty za postój pojazdów samochodowych na drogach publicznych w Polsce reguluje ustawa o drogach publicznych ${ }^{1}$. Zgodnie z art. 13 u.d.p. korzystający z dróg publicznych są obowiązani do ponoszenia opłat za postój pojazdów samochodowych na drogach publicznych:

1) w strefie płatnego parkowania ${ }^{2}$ (dalej: SPP i odpowiednio opłata SPP lub o.SPP),

2) w śródmiejskiej strefie płatnego parkowania ${ }^{3}$ (dalej: ŚSPP i odpowiednio o.ŚSPP).

Przedmiotem niniejszego opracowania jest przybliżenie konstrukcji prawnej obu ww. opłat. W tym celu posłużono się odnośnymi aktami prawnymi, poglądami doktryny oraz orzecznictwem sądowym.

Zanim jednak analizie poddane zostaną szczegółowe regulacje dotyczące opłaty SPP i opłaty ŚSPP, warto ustalić znaczenie terminów: „postój pojazdu”, „pojazd samochodowy”, „droga publiczna” oraz „korzystający z drogi publicznej”, ponieważ tymi pojęciami posługuje się ustawodawca przy określaniu zakresu podmiotowego i przedmiotowego tych opłat.

W u.d.p. nie zdefiniowano terminu „postój pojazdu”. Definicję „postoju pojazdu” zawiera natomiast Prawo o ruchu drogowym ${ }^{4}$. Z uwagi na

1 Ustawa z dnia 21 marca 1985 r. o drogach publicznych (tekst jedn. Dz.U. z 2020 r. poz. 470), dalej: u.d.p.

2 Opłatę SPP wprowadziła z dniem 24 listopada 2003 r. ustawa z dnia 14 listopada 2003 r. o zmianie ustawy o drogach publicznych oraz o zmianie niektórych innych ustaw (Dz.U. Nr 200, poz. 1953 ze zm.).

3 Opłatę ŚSPP wprowadziła z dniem 5 września 2019 r. ustawa z dnia 5 lipca 2018 r. o zmianie ustawy o partnerstwie publiczno-prywatnym oraz niektórych innych ustaw (Dz.U. poz. 1693). 
przynależność u.d.p. i P.r.d. do tej samej gałęzi prawa wydaje się zasadnym krzyżowe poszukiwanie znaczeń użytych w nich pojęć - oczywiście jedynie w sytuacji braku stosownej definicji w ustawie, w której dany termin pojawia się. W myśl art. 2 pkt 30 P.r.d. postojem pojazdu jest unieruchomienie pojazdu niewynikające z warunków lub przepisów ruchu drogowego, trwające dłużej niż 1 minutę.

W u.d.p. nie odnajdziemy również definicji „pojazdu samochodowego”. W tym przypadku z pomocą przychodzi także P.r.d. W myśl art. 2 pkt 33 P.r.d. pojazdem samochodowym jest pojazd silnikowy (inny niż ciągnik rolniczy), którego konstrukcja umożliwia jazdę z prędkością przekraczającą $25 \mathrm{~km} / \mathrm{h}$. Z kolei pojazdem silnikowym jest pojazd silnikowy jest pojazd wyposażony w silnik, z wyjątkiem motoroweru i pojazdu szynowego, a pojazdem jest środek transportu przeznaczony do poruszania się po drodze oraz maszyna lub urządzenie do tego przystosowane (art. 2 pkt 31 i 32 P.r.d.).

U.d.p. zawiera z kolei definicję „drogi publicznej”. Stosownie do art. 1-3 u.d.p. drogą publiczną jest droga zaliczona na podstawie u.d.p. do jednej z kategorii dróg, z której może korzystać każdy, zgodnie z jej przeznaczeniem, z ograniczeniami i wyjątkami określonymi w u.d.p. lub innych przepisach szczególnych. Drogi publiczne ze względu na funkcje w sieci drogowej dzielą się na drogi: krajowe, wojewódzkie, powiatowe i gminne. Ulice leżące w ciągu danej drogi należą do tej samej kategorii co te drogi. Drogi krajowe stanowią własność Skarbu Państwa. Drogi wojewódzkie, powiatowe i gminne stanowią własność właściwego samorządu województwa, powiatu lub gminy. Drogi publiczne ze względu na ich dostępność dzielą się na: drogi ogólnodostępne oraz drogi o ograniczonej dostępności, w tym autostrady i drogi ekspresowe.

Podobnie jak w odniesieniu do „postoju pojazdu” i „pojazdu samochodowego” w u.d.p. nie ma definicji legalnej terminu „korzystający z drogi publicznej”. W tym przypadku nie odnajdziemy jej również w P.r.d. Stąd też w drodze wykładni językowej i funkcjonalnej przyjmuje się, że korzystającym z drogi publicznej w rozumieniu art.13 u.d.p. jest

4 Ustawa z dnia 20 czerwca 1997 r. Prawo o ruchu drogowym (tekst jedn. Dz.U. z 2021 r. poz. 450 ze zm.), dalej: P.r.d. 
osoba fizyczna lub jednostka organizacyjna (m.in. osoba prawna oraz jednostka niemająca osobowości prawnej), która we własnym imieniu lub na której rzecz następuje użytkowanie drogi publicznej. Skoro ustawodawca nie wprowadza jakiegokolwiek zawężenia podmiotowego w tym zakresie, za korzystającego z drogi publicznej uznać należy zarówno właściciela pojazdu, posiadacza zależnego pojazdu (m.in. najemca, dzierżawca, biorący w umowie użyczenia), jak i użytkownika bez tytułu prawnego, w tym złodzieja lub pasera ${ }^{5}$.

Po ustaleniu znaczenia najważniejszych pojęć z punktu widzenia omawianego tematu można przystąpić do analizy szczegółowych zagadnień.

W artykule uwzględniono stan prawny z 1 marca 2021 r.

\section{Analiza prawna o.SPP i o.ŚSPP}

\subsection{Opłata za parkowanie w strefie płatnego parkowania}

Zgodnie z art. 13 ust. 1 pkt 1 lit. a u.d.p. korzystający z dróg publicznych są obowiązani do ponoszenia opłaty za postój pojazdów samochodowych na drogach publicznych w strefie płatnego parkowania (opłata SPP).

W kompetencję do ustanawiania na terenie danej gminy SPP wyposażona została rada gminy (organ stanowiący), która może to uczynić w drodze uchwały, stanowiącej akt prawa miejscowego, podjętej na wniosek wójta (burmistrza, prezydenta miasta), zaopiniowany przez organy zarządzające drogami i ruchem na drogach (art. 13b ust. 3 u.d.p.). Uprawnienie to ma jednak charakter fakultatywny. Istotnych wytycznych w przedmiocie tego, kiedy SPP powinna być utworzona (lecz w dalszym ciągu nie jest to obligatoryjne), udziela ustawodawca w art. 13b ust. 2 u.d.p., który stanowi, że SPP „ustala się na obszarach charakteryzujących się znacznym deficytem miejsc postojowych, jeżeli uzasadniają to potrzeby organizacji ruchu, w celu zwiększenia rotacji parkujących pojazdów

5 R.A. Rychter, Ustawa o drogach publicznych. Komentarz, LEX/el. 2019, komentarz do art. 13. 
samochodowych lub realizacji lokalnej polityki transportowej, w szczególności w celu ograniczenia dostępności tego obszaru dla pojazdów samochodowych lub wprowadzenia preferencji dla komunikacji zbiorowej”. Z przepisu tego wynika, że SPP powinna być narzędziem służącym przede wszystkim do ograniczenia ruchu pojazdów samochodowych w miejscach, w których pojawiają się problemy ze zbyt dużym natężeniem ruchu (przede wszystkim centrum miasta), oraz narzędziem wsparcia dla publicznego transportu zbiorowego (z jednej strony mniejszy ruch pojazdów usprawnia tę komunikację, z drugiej strony SPP ma w założeniu zwiększyć popyt na ten rodzaj usług komunalnych).

Art. 13b ust. 1 i 4 u.d.p. oraz art. 13f ust. 2 u.d.p. wymieniają władcze obowiązki rady gminy, które towarzyszą pojęciu uchwały o ustanowieniu SPP. Część z nich ma charakter obligatoryjny, a zatem stosowne postanowienia muszą znaleźć się w uchwale o ustanowieniu SPP (zdaniem autora takie rozwiązanie z legislacyjnego i z praktycznego punktu widzenia jest optymalne - może to być również osobna uchwała), a część z nich ma charakter fakultatywny i o ich przyjęciu decyduje swobodnie organ stanowiący. Obligatoryjnie w uchwale o ustanowieniu SPP znaleźć się muszą postanowienia dotyczące:

1) obszaru, na którym ustanawia się SPP;

2) czasu, kiedy postój na obszarze SPP wiąże się z uiszczeniem o.SPP;

3) wysokości o.SPP;

4) wysokości opłaty dodatkowej należnej za nieuiszczenie o.SPP;

5) sposobu poboru o.SPP i opłaty dodatkowej.

Fakultatywnymi elementami uchwały o ustanowieniu SPP są natomiast postanowienia dotyczące:

1) rodzajów, wysokości i sposobu uiszczania opłaty abonamentowej lub opłaty zryczałtowanej za postój w SPP;

2) zerowej stawki o.SPP dla niektórych użytkowników drogi ${ }^{6}$.

6 Niezależnie od decyzji organu stanowiącego gminy w tym zakresie na mocy art. 13 ust. 3 i 5 u.d.p. od o.SPP zwolnione są wymienione w tych przepisach pojazdy. Są to m.in. pojazdy służb mundurowych, służby zdrowia, Sił Zbrojnych RP, autobusy szkolne, ale także pojazdy elektryczne. 
Obowiązek wyznaczenia obszaru SPP realizowany jest najczęściej poprzez wskazanie w uchwałach w sprawie utworzenia SPP nazw ulic, alei, placów itp., na których parkowanie wiąże się z uiszczeniem o.SPP. Częstym elementem uchwały jest także graficzny załącznik prezentujący granice SPP na planie danej gminy.

Organy stanowiące gmin są władne ustanowić o.SPP jedynie w dni robocze, w określonych godzinach lub całodobowo. A contrario postój w SPP poza wyznaczonym czasem w dni robocze (najczęściej pora nocna) lub całodobowo $\mathrm{w}$ dni ustawowo wolne od pracy nie wiąże się z obowiązkiem ponoszenia o.SPP przez kierujących pojazdami samochodowymi. Zagadnienie rozumienia terminu „dzień roboczy” na gruncie o.SPP jest szerzej analizowane w drugiej części niniejszego opracowania.

W myśl art. 13b ust. 4 pkt 1 u.d.g. wysokość określonej przez organ stanowiący gminy o.SPP za pierwszą godzinę postoju pojazdu samochodowego nie może przekraczać $0,15 \%$ minimalnego wynagrodzenia za pracę. Minimalne wynagrodzenie za pracę w 2021 r. wynosi 2800 zł brutto, zatem wysokość o.SPP za pierwszą godzinę postoju nie może przekraczać 4,2 zł $(0,15 \%$ × 2800 zł). Do niedawna wysokość opłaty za pierwszą godzinę postoju była określana kwotowo i wynosiła maksymalnie 3 zł. Nową regulację, wiążąca wysokość opłaty za postój w SPP z minimalnym wynagrodzeniem za pracę, należy ocenić pozytywnie. Stawka opłaty określona w ten sposób będzie stale zachowywała relatywnie ten sam ciężar finansowy z uwagi na coroczny wzrost minimalnego wynagrodzenia za pracę.

Zgodnie z art. 13b ust. 5 u.d.g. „przy ustalaniu stawek uwzględnia się progresywny wzrost opłaty przez pierwsze trzy godziny postoju, przy czym progresja nie może przekraczać powiększenia stawki opłaty o $20 \%$ za kolejne godziny w stosunku do stawki za poprzednią godzinę postoju. Stawka opłaty za czwartą godzinę i za kolejne godziny postoju nie może przekraczać stawki opłaty za pierwszą godzinę postoju”. Językowa wykładnia przytoczonych przepisów prowadzi do wniosku, że organ stanowiący gminy ma obowiązek określać (na co wskazuje użyte przez usta-

7 W rozumieniu art. 2 ust. 1 ustawy z dnia 10 października 2002 r. o minimalnym wynagrodzeniu za pracę (tekst jedn. Dz.U. z 2020 r. poz. 2207). 
wodawcę stanowcze sformułowanie „uwzględnia się”) o.SPP w coraz to wyższej wysokości za kolejne trzy pierwsze godziny postoju (nie może zatem określić tych stawek w tej samej wysokości bądź malejąco za kolejne godziny postoju), z tymi zastrzeżeniami, że opłata za pierwszą godzinę postoju może wynieść maksymalnie w 2021 r. 4,2 zł, a opłata za kolejną godzinę postoju nie może być wyższa o więcej niż 20\% w odniesieniu do opłaty za godzinę poprzednią. Natomiast opłata za czwartą i każdą następną godzinę postoju nie może być wyższa niż opłata za pierwszą godzinę postoju ${ }^{8}$.

Zrozumieniu powyższych zasad może pomóc przykład, w którym organ stanowiący gminy określił stawkę o.SPP za pierwszą godzinę postoju w kwocie 2 zł (w 2021 r. mógł maksymalnie 4,2 zł). Zatem stawka o.SPP za drugą godzinę postoju może wynieść od 2,01 zł do 2,4 zł ${ }^{9}$. Zakładając, że organ określił ją w kwocie 2,2 zł, to wtedy stawka o.SPP za trzecią godzinę wynieść może od 2,21 zł do 2,64 $\mathrm{zł}^{10}$. W podanym przykładzie stawka

8 Wątpliwości może budzić zagadnienie, czy o.SPP za czwartą i każdą następną godzinę postoju może wynosić maksymalnie tyle, ile organ stanowiący danej gminy ustalił dla pierwszej godziny postoju, czy też odnieść ją można wprost do maksymalnej ustawowej wartości, czyli $0,15 \%$ minimalnego wynagrodzenia za pracę w danym roku. To znaczy, czy dopuszczalnym byłoby określenie przez daną radę gminy o.SPP za pierwszą godzinę postoju w wysokości np. 2 zł, a następnie za czwartą i każdą następną godzinę postoju w wysokości niższej lub wyższej, lecz mieszczącej się w kwocie $0,15 \%$ minimalnego wynagrodzenia za pracę w danym roku; czy też w takiej sytuacji górny limit opłaty za ten czas to również 2 zł. Językowa wykładnia art. 13b ust. 5 u.d.p. prowadzi do wniosku, że stawka o.SPP za pierwszą godzinę postoju stanowi jednocześnie pułap stawki o.SPP za czwartą i każdą następną godzinę postoju i organ stanowiący gminy nie może określić tej drugiej stawki w wyższej wysokości. Autor pogląd ten uzasadnia użyciem przez ustawodawcę sformułowania „nie może przekraczać stawki opłaty za pierwszą godzinę postoju”. Gdyby ustawodawca chciał pozostawić gminom większą swobodę w zakresie kształtowania o.SPP za postój trwający ponad trzy godziny, to użyłby sformułowania o treści np. „nie może przekraczać maksymalnej stawki opłaty za pierwszą godzinę postoju". Na marginesie zauważyć należy, że w odniesieniu do stawki o.SPP za czwartą i każdą następną godzinę postoju zastosowania nie ma reguła „maksymalnie 20\% progresji”, występująca przy stawkach o.SPP za pierwsze trzy godziny postoju.

9 Maksymalną wartość stawki o.SPP za drugą godzinę postoju stanowi: 2 zł $+20 \% \times 2$ zł $=2 \mathrm{zl}+0,4 \mathrm{zl}=2,4 \mathrm{zl}$.

10 Maksymalną wysokość stawki o.SPP za trzecią godzinę postoju stanowi: 2,2 zł + 20\% $\times 2,2 \mathrm{zł}=2,2 \mathrm{zł}+0,44 \mathrm{zł}=2,64 \mathrm{zł}$. 
o.SPP za czwartą i każdą następną godzinę postoju nie może wtedy przekroczyć kwoty 2 zł, tj. wysokości stawki za pierwszą godzinę postoju.

Art. 13b ust. 5 u.d.p. zawiera jeszcze jedną ważną regulację dotyczącą określania wysokości stawek o.SPP, a mianowicie dopuszcza możliwość różnicowania wysokości stawek w zależności od miejsca postoju w SPP. W praktyce zastosowanie tej możliwości polega najczęściej na podziale SPP na podstrefy, w których obowiązują różne stawki o.SPP.

\subsection{Opłata za parkowanie w śródmiejskiej strefie płatnego parkowania}

Zgodnie z art. 13 ust. 1 pkt 1 lit. b u.d.p. korzystający z dróg publicznych są obowiązani do ponoszenia opłaty za postój pojazdów samochodowych na drogach publicznych w śródmiejskiej strefie płatnego parkowania (opłata ŚSPP).

Kompetencje rady gminy w odniesieniu do opłaty ŚSPP kształtują się analogicznie jak w przypadku opłaty SPP (patrz sekcja 2.2.).

Odmienność opłaty ŚSPP względem opłaty SPP polega na tym, że:

1) o.ŚSPP może być pobierana w dowolnym czasie, tj. także w soboty i niedziele - istnieje prawna możliwość ustanowienia ŚSPP obowiązującej 24 godziny w każdym z 7 dni tygodnia;

2) ŚSPP ustala się na obszarach zgrupowania intensywnej zabudowy funkcjonalnego śródmieścia, które stanowi faktyczne centrum miasta, lub dzielnicy w mieście o liczbie ludności powyżej 100000 mieszkańców, jeżeli spełnione są warunki do ustanowienia SPP, lecz ustanowienie SPP może nie być wystarczające do realizacji lokalnej polityki transportowej lub polityki ochrony środowiska;

3) ustalenie ŚSPP, w tym ustalenie wysokości o.ŚSPP, wymaga uprzedniego przeprowadzenia przez wójta (burmistrza, prezydenta miasta) analizy, która określi rotację parkujących pojazdów samochodowych w planowanej śródmiejskiej strefie płatnego parkowania oraz zakładany poziom rotacji parkujących pojazdów samochodowych $\mathrm{w}$ planowanej śródmiejskiej strefie płatnego parkowania, z uwzględnieniem różnych poziomów wysokości opłat za postój w tej strefie; 
4) wysokość o.ŚSPP za pierwszą godzinę postoju może wynieść maksymalnie $0,45 \%$ minimalnego wynagrodzenia za pracę, tj. 12,6 zł w 2021 r. (obowiązuje identyczna zasada 20\% progresji, jak w o.SPP).

\subsection{Opłata dodatkowa za nieuiszczenie o.SPP i o.ŚSPP}

W myśl art. $13 f$ ust. 1 u.d.p. za nieuiszczenie o.SPP pobiera się od korzystającego z drogi publicznej opłatę dodatkową. Przez nieuiszczenie o.SPP należy rozumieć zarówno sytuację, kiedy korzystający z drogi publicznej w ogóle nie opłacił postoju, jak i sytuację, kiedy wniesiona o.SPP nie pokrywa faktycznego czasu trwania postoju w SPP.

Określona przez radę gminy wysokość opłaty dodatkowej nie może obecnie przekraczać $10 \%$ minimalnego wynagrodzenia za pracę, a zatem w 2021 r. maksymalna wysokość opłaty dodatkowej wynosi 280 zł (art. 13f ust. 2 u.d.p.). Natomiast z punktu widzenia wartości minimalnej opłaty dodatkowej jej cel będzie spełniony, jeżeli będzie wynosiła odczuwalnie więcej niż koszt parkowania pojazdu przez cały dzień, ponieważ jej sens sprowadza się do skłonienia użytkowników dróg publicznych do rzetelnego uiszczania opłaty SPP i ŚSPP. Ponadto należy mieć na uwadze okoliczność, że wraz z wystawieniem wezwania do uiszczenia opłaty dodatkowej (przez uprawnionego kontrolera) nie idzie w parze obowiązek uiszczenia opłaty SPP/ŚSPP za nieopłacony czas postoju (zasada ta wynika głównie z trudności natury dowodowej, bowiem często nie da się ustalić czasu nieopłaconego postoju).

Zastanawiające jest zagadnienie liczby opłat dodatkowych, które można naliczyć względem danego pojazdu w ciągu jednego dnia obowiązywania SPP/ŚSPP. Kwestii tej nie rozstrzyga wprost u.d.p. Autor stoi na stanowisku, że opłatę dodatkową należy traktować również jako faktycznie spełniającą funkcję opłaty dobowej za postój pojazdu w SPP, co jest logiczną konsekwencją okoliczności, że wraz z poborem opłaty dodatkowej nie pobiera się równolegle o.SPP i o.ŚSPP i co prowadzi do wniosku, że postój danego pojazdu w SPP/ŚSPP może być obciążony opłatą dodat- 
kową wyłącznie jednokrotnie $\mathrm{w}$ danym dniu obowiązywania $\mathrm{SPP}^{11}$. Nie ma w tym kontekście znaczenia, że pojazd zmieniał miejsce postoju w ciągu danego dnia (w szczególności, że parkował w różnych podstrefach), chyba że w poszczególnych podstrefach przewidziane są różne stawki opłaty dodatkowej. W takiej sytuacji rozsądnym wydaje się pogląd, że posiadacz pojazdu będzie zobowiązany do zapłaty jednej, najwyższej opłaty dodatkowej spośród wymierzonych. Ponadto uznać należy, że opłata dodatkowa jest ściśle powiązana z nieopłaconym postojem konkretnego pojazdu, zatem nie jest wykluczone, że za dany dzień jedna osoba stanie się zobowiązana do wniesienia kilku opłat dodatkowych w sytuacji, gdy nie opłaci należycie postoju kilku pojazdów.

Podmiot uprawniony do poboru opłaty dodatkowej, tj. zarząd drogi, a w razie jego braku zarządca drogi, w związku z jej poborem jest zobowiązany do realizacji obowiązków informacyjnych wynikających z art. 13 ust. 1 i 2 Rozporządzenia Parlamentu Europejskiego i Rady (UE) 2016/679 z dnia 27 kwietnia 2016 r. w sprawie ochrony osób fizycznych w związku z przetwarzaniem danych osobowych i w sprawie swobodnego przepływu takich danych oraz uchylenia dyrektywy 95/46/WE ${ }^{12}$ (ogólne rozporządzenie o ochronie danych - zwane powszechnie RODO) i polegających na przekazaniu osobie, której dane osobowe w związku z poborem opłaty dodatkowej są przetwarzane, informacji m.in. o podmiocie gromadzącym dane osobowe i celu ich przetwarzania.

Obowiązujące przepisy pozwalają na precyzyjne ustalenie podmiotu będącego wierzycielem i organem egzekucyjnym opłaty dodatkowej za parkowanie. Będzie to organ administracji publicznej, któremu art. 19 u.d.p. przyznaje kompetencje zarządcy drogi ${ }^{13}$.

Stosownie do art. $13 f$ ust. 5 u.d.p. osoba, której dane osobowe dotyczą, ma prawo żądania od administratora ograniczenia ich przetwarzania

11 Rzecz jasna w ramach SPP w danym mieście. Nie ma prawnych przeszkód do wymierzenia opłaty dodatkowej względem jednego pojazdu, którego postój był nieopłacony w ciągu doby w różnych miastach, gdzie SPP obowiązuje.

12 Dz.Urz. UE L 2016, Nr 119, s. 1.

13 K. Sobieralski, Wierzyciel $w$ postępowaniu egzekucyjnym $w$ administracji opłaty dodatkowej za parkowanie pojazdów samochodowych na drogach publicznych w strefie płatnego parkowania, „Nowe Zeszyty Samorządowe” 2008, nr 6, s. 40. 
w ściśle określonych w art. 18 ust. 1 RODO przypadkach. Skorzystanie z tego uprawnienia nie wpływa jednak na obowiązek uiszczenia opłaty dodatkowej.

\subsection{Sposób nałożenia i poboru o.SPP, o.ŚSPP i opłaty dodatkowej}

Przed poruszeniem kwestii sposobu nałożenia na korzystającego z drogi publicznej analizowanych w niniejszym opracowaniu opłat warto zwrócić uwagę na art. 40a ust. 1 u.d.p., zgodnie z którym o.SPP, o.ŚSPP oraz opłata dodatkowa stanowią dochód jednostki samorządu terytorialnego (względnie Generalnej Dyrekcji Dróg Krajowych i Autostrad). Ponadto stosownie do art. 40a ust. 1d u.d.p. środki uzyskane z o.ŚSPP, w wysokości nie mniejszej niż 65\% tych opłat, oraz 100\% środków z opłat dodatkowych pobranych z tytułu nieuiszczenia o.ŚSPP (nie dotyczy o.ŚPP!) gmina przeznacza wyłącznie na sfinansowanie poprawy publicznego transportu zbiorowego, budowę lub przebudowę infrastruktury pieszej lub rowerowej lub zieleń i zadrzewienia w gminie.

Obowiązek uiszczenia o.SPP i o.ŚSPP powstaje z mocy samego prawa w chwili zaparkowania pojazdu w wyznaczonym miejscu postojowym na obszarze SPP. Kwota uiszczonej opłaty zależy od woli osoby dokonującej opłaty i powinna odpowiadać przewidywanemu czasowi postoju pojazdu przy uwzględnieniu wysokości stawek opłaty. W praktyce spotyka się dwa główne sposoby uiszczenia tej opłaty:

1) uiszczenie opłaty w parkometrze za pokwitowaniem, które wskazuje datę i godzinę, do której opłacony został postój i które powinno zostać umieszczone $\mathrm{w}$ samochodzie, w widocznym z zewnątrz miejscu (np. za przednią szybą pojazdu) w celu umożliwienia skontrolowania prawidłowej realizacji obowiązku uiszczenia opłaty przez upoważnionego pracownika zarządu drogi;

2) uiszczenie opłaty za pomocą odpowiedniej aplikacji mobilnej zainstalowanej $\mathrm{w}$ telefonie komórkowym. Po uiszczeniu opłaty $\mathrm{w}$ ten sposób aplikacja mobilna łączy się z odpowiednią bazą danych (do której mają dostęp kontrolerzy) i dokonuje w niej wpisu obejmujące- 
go markę i numer rejestracyjny pojazdu oraz datę i godzinę, do której opłacony został postój; korzystając z tej metody opłacania postoju w SPP, nie otrzymuje się żadnego fizycznego pokwitowania, a zatem chcąc poinformować kontrolera o uiszczeniu opłaty, najlepiej odpowiednio oznaczyć pojazd, np. specjalną naklejką sugerującą korzystanie z mobilnej formy opłacania postoju w $\mathrm{SPP}^{14}$.

Nie istnieje żadna prawna procedura egzekwowania uiszczenia o.SPP i o.ŚSPP. Nieuiszczenie tych opłat kompensowane jest obowiązkiem zapłaty opłaty dodatkowej (art. 13f u.d.p.).

Podobnie jak w przypadku o.SPP i o.ŚSPP obowiązek uiszczenia opłaty dodatkowej powstaje z mocy samego prawa w sytuacji nieopłacenia postoju w SPP lub ŚSPP. Opłata dodatkowa nie jest karą (mandatem), lecz ekwiwalentem za parkowanie pojazdu na drodze publicznej (korzystanie z drogi w sposób określony w ustawie) w miejscu, w którym za takie parkowanie pobierane są opłaty. Obowiązek uiszczenia opłaty dodatkowej w praktyce aktualizuje się w razie ujawnienia przez upoważnionego kontrolera nieopłaconego postoju pojazdu w SPP lub ŚSPP. Podkreślenia wymaga, że kontroler wystawia w takim przypadku zawiadomienie o obowiązku uiszczenia opłaty dodatkowej i dla celów dowodowych powinien np. wykonać zdjęcie pojazdu z nieopłaconym postojem. Sporządzane przez kontrolerów obsługujących SPP i ŚSPP zawiadomienia o nieopłaconym postoju w strefie płatnego parkowania, którego oryginał umieszczany jest za wycieraczką pojazdu, stanowi dokument potwierdzający nieuiszczenie opłaty, a zarazem jest dla korzystającego z drogi dodatkową informacją o (powstałym z mocy prawa) obowiązku uiszczenia opłaty dodatkowej. Przepisy obowiązującego prawa nie wymagają, aby dokumenty wystawiane przez pracowników zarządcy drogi w sytuacji nieuiszczenia opłaty za parkowanie pojazdu były imienne ${ }^{15}$. Zawiadomie-

14 Brak naklejki nie wywołuje jednak żadnych negatywnych skutków, ponieważ w sytuacji, gdy kontroler odnotował brak pokwitowania z parkometru i brak informacji o stosowaniu płatności mobilnych, ma i tak obowiązek sprawdzić dokonanie płatności mobilnej. Z drugiej strony wspomniana naklejka nie oznacza przecież, że postój został mobilnie opłacony.

15 Wyrok WSA w Gliwicach z dnia 3 listopada 2015 r., I SA/Gl 664/15, LEX nr 1958904. 
nie to nie jest decyzją administracyjną, a zatem nie podlega rygorom doręczenia właściwym dla pisma w postępowaniu administracyjnymi ${ }^{16}$.

Nie oznacza to jednak, że obowiązek uiszczenia opłaty dodatkowej ma charakter definitywny. Zgodnie z art. 13f ust. 2 u.d.p. na radzie gminy ciąży obowiązek określenia sposobu poboru opłaty dodatkowej. Wydaje się, że w zakresie realizacji tego obowiązku mieści się również ustanowienie swoistej procedury reklamacyjnej ${ }^{17}$, której celem jest umorzenie tych opłat dodatkowych, co do których nie ziściły się warunki powstania obowiązku ich zapłaty (np. wezwano do uiszczenia opłaty dodatkowej za postój pojazdu, który był należycie opłacony, lub za postój w czasie, w którym postój nie podlega opłacie) lub obowiązek zapłaty opłaty dodatkowej został skierowany do niewłaściwej osoby.

Ani na wierzycielu (co do zasady zarząd drogi), ani na organie egzekucyjnym (co do zasady naczelnik urzędu skarbowego właściwy ze względu na miejsce zamieszkania zobowiązanego) nie ciąży obowiązek ustalenia osoby korzystającej z drogi publicznej (parkującej samochód w SPP lub ŚSSP). Obowiązek ten spoczywa bowiem na zobowiązanym (co do zasady jest nim korzystający z drogi publicznej), gdyż to on, podnosząc tę okoliczność, zamierza wywołać określony skutek prawny w postaci uchylenia się od odpowiedzialności ${ }^{18}$.

W orzecznictwie sądów administracyjnych odnaleźć można pogląd, zgodnie z którym „skoro korzystającym z pojazdu samochodowego, a tym samym z drogi publicznej, jest z reguły jego właściciel (współwłaściciel), to $\mathrm{w}$ razie stwierdzenia braku wniesienia opłaty parkingowej we właścicielu pojazdu należy upatrywać zobowiązanego do uiszczenia opłaty dodatkowej, chyba że ten wykaże, iż wyzbył się władztwa fizycznego nad pojazdem na rzecz innej osoby, czy to na skutek własnego oświadczenia woli, czy wbrew własnej woli”19.

16 Porównaj wyrok NSA z dnia 11 marca 2009 r., I OSK 1513/08, LEX nr 532606.

17 Odmiennie K. Sobieralski, Reklamacja należnych opłat dodatkowych za parkowanie, „Nowe Zeszyty Samorządowe” 2010, nr 4, s. 21 i n.

18 K. Sobieralski, Reklamacja..., „Nowe Zeszyty Samorządowe” 2010, nr 4, s. 21 i n.

19 Wyrok WSA w Poznaniu z dnia 17 maja 2018 r., I SA/Po 245/18, LEX nr 2498758. 
Zatem właściciel pojazdu, który uważa, że to nie względem niego powinno zostać wystosowane wezwanie do uiszczenia opłaty dodatkowej, powinien wykazać przed organem nakładającym opłatę dodatkową, że to nie on, jako właściciel, korzystał z parkowania na drodze publicznej. Musi przedstawić dowody wskazujące na to, że inne osoby korzystały z pojazdu jako posiadacze zależni i nie uiściły wymaganych opłat parkingowych, dzięki czemu będzie im można przypisać cechę zobowiązanych z tytułu opłaty dodatkowej za parkowanie. Takim dowodem nie może być jednak przekazanie danych osobowych kilku osób i sugerowanie, że to organ powinien wskazać, która z nich ponosi odpowiedzialność za brak poniesionej opłaty ${ }^{20}$.

Dopuszczalność egzekucji administracyjnej opłaty dodatkowej za parkowanie w strefie płatnego parkowania uzależniona jest od wymagalności tego świadczenia. Opłata dodatkowa staje się wymagalna z chwilą stwierdzenia przez upoważnionego pracownika zarządu drogi (lub pracownika zarządcy drogi) faktu nieuiszczenia opłaty za parkowanie (względnie przekroczenia czasu postoju ponad opłacony czas) ${ }^{21}$.

\subsection{Stosowanie Ordynacji podatkowej do o.SPP, o.ŚSPP i opłaty dodatkowej}

Na gruncie omawianego zagadnienia powstaje zasadnicza wątpliwość dotycząca możliwości odpowiedniego stosowania Ordynacji podatkowej ${ }^{22}$ do o.SPP, o.ŚSPP i wynikającej z ich nieuiszczenia opłaty dodatkowej (w zakresie nieuregulowanym w u.d.p.). Nakreślony problem jest szczególnie istotny w odniesieniu do opłaty dodatkowej. Niestety, u.d.p. nie zawiera przepisu, który wprost stanowiłby o stosowaniu (albo niestosowaniu) Ordynacji podatkowej do ww. opłat. Sprawę ponadto komplikuje art. 40d u.d.p., którego zakres normowania pokrywa się z treścią:

\footnotetext{
K. Sobieralski, Reklamacja..., „Nowe Zeszyty Samorządowe” 2010, nr 4, s. 21 i n. Tamże, s. 21 i n.

22 Ustawa z dnia 29 sierpnia 1997 r. Ordynacja podatkowa (tekst jedn. Dz.U. z 2020 r. poz. 1325).
} 
1) art. $70 \S 1$ Ordynacji podatkowej (art. 40d ust. 3 u.d.p.) - poprzez regulację, że obowiązek uiszczenia m.in. opłaty dodatkowej przedawnia się z upływem 5 lat, licząc od ostatniego dnia roku kalendarzowego, w którym opłata dodatkowa powinna zostać uiszczona;

2) a contrario z treścią art. $53 \S 1$ Ordynacji podatkowej (art. 40d ust. 1 u.d.p.) - poprzez regulację, że od nieuiszczonej w terminie opłaty dodatkowej nie nalicza się odsetek za zwłokę.

Rozstrzygnięcie poruszonej kwestii ma doniosłe konsekwencje, chociażby dla zasad zawieszania i przerywania terminów przedawnienia, które znajdą zastosowanie do ww. pięcioletniego terminu przedawnienia uiszczenia opłaty dodatkowej.

W zakresie omawianego zagadnienia w orzecznictwie sądów administracyjnych wytworzyły się dwie odmienne i licznie reprezentowane linie orzecznicze $^{23}$. W myśl pierwszej z nich należności z tytułu opłaty SPP i opłaty ŚSPP przedawniają się z upływem pięciu lat, licząc od końca roku kalendarzowego, w którym opłaty te powinny zostać uiszczone, a przerwanie, zawieszenie lub wydłużenie biegu terminu przedawnienia nie jest w tym przypadku możliwe ${ }^{24}$. Stosownie do drugiej z nich do przedawnie-

23 M.Z. Sondej, Zastosowanie przepisów Ordynacji podatkowej względem przedawnienia opłaty dodatkowej za parkowanie w strefie płatnego parkowania, LEX/el. 2020.

24 Pogląd ten odnaleźć można m.in. w wyrokach: WSA w Gdańsku z dnia 22 maja 2019 r., I SA/Gd 594/19, LEX nr 2691887 (,nie istnieje żadna podstawa prawna, zgodnie z którą do należności z tytułu opłaty dodatkowej za nieuiszczenie opłaty za parkowanie miałyby zastosowanie przepisy Działu III Ordynacji podatkowej, w tym art. 70 § 4, dotyczący przerwania biegu terminu przedawnienia. Zdaniem przedstawicieli tego nurtu interpretacyjnego uregulowanie zawarte w art. 40d ust. 3 u.d.p. stanowi odrębną i całościową regulację kwestii przedawnienia tych należności, w u.d.p., jak i w jakiejkolwiek innej ustawie, brak jest bowiem w tym zakresie odesłania do przepisów Ordynacji podatkowej”), WSA w Krakowie z dnia 24 kwietnia 2019 r., I SA/Kr 9/19, LEX nr 272245, NSA z dnia 29 stycznia 2019 r., II FSK 2904/18, LEX nr 2628163 (,z uwagi na tak skonstruowane przepisy oraz odesłanie znajdujące się w art. 67 Ustawy z dnia 27 sierpnia 2009 r. o finansach publicznych (tekst jednolity: Dz.U. z 2019 r. poz. 869; dalej: u.f.p.) brak jest podstaw prawnych do zastosowania w niniejszej sprawie art. 70 § 4 Ordynacji podatkowej Zdaniem Naczelnego Sądu Administracyjnego przepisy ustawy o drogach publicznych stanowią lex specialis $\mathrm{w}$ stosunku do ww. przepisów Ordynacji podatkowej i ustawy o finansach publicznych. Przepisy ustawy o drogach publicznych bowiem w sposób zupełny i odrębny od zasady ogólnej wynikającej z treści art. $70 \S 4$ Ordynacji podatkowej w zw. z art. 67 u.f.p., regulują zasady przedawniania opłat i kar, o których mowa w tej ustawie. (...) Ustawodawca nie 
nia należności z tytułu opłaty dodatkowej odpowiednie zastosowanie mają przepisy Ordynacji podatkowej, w tym regulacja dotycząca przerywania i zawieszania terminu przedawnienia ${ }^{25}$. Istniejąca dwutorowa praktyka orzecznicza jest zdecydowanie niepożądanym zjawiskiem i powinna stanowić przyczynek do podjęcia przez ustawodawcę działań, których skutkiem powinno być ustawowe rozstrzygnięcie tego sporu.

W uzupełnieniu do ww. niejednolitego orzecznictwa warto w tym miejscu przedstawić poglądy doktryny, które są w tym względzie bardziej

przewidział w obowiązujących przepisach możliwości przerwania biegu terminu przedawnienia. Istota przedawnienia nie musi być powiązana z przerwaniem biegu terminu przedawnienia. To rozwiązanie nie jest immanentną cechą przedawnienia. Brak jakichkolwiek odesłań do innych uregulowań w zakresie przerwy, prolongaty lub zawieszenia biegu terminu przedawnienia opłat pozwala na wniosek, że ustawodawca w sposób kompletny i zupełny określił pięcioletni termin przedawnienia obowiązku zapłaty bez możliwości przedłużania tego okresu”), WSA w Warszawie z dnia 27 września 2018 r., V SA/Wa 757/18, LEX nr 2570857, WSA w Warszawie z dnia 27 września 2018 r., V SA/Wa 834/18, LEX nr 2579479, WSA w Warszawie z dnia 28 sierpnia 2018 r., V SA/Wa 778/18, LEX nr 2572435, WSA w Poznaniu z dnia 5 lipca 2018 r., I SA/Po 410/18, LEX nr 2525274, WSA w Poznaniu z dnia 10 maja 2018 r., I SA/Po 197/18, LEX nr 2503279, WSA w Gdańsku z dnia 13 maja 2018 r., I SA/Gd 96/18, LEX nr 2478587, WSA w Olsztynie z dnia 7 marca 2018 r., I SA/Ol 95/18, LEX nr 2472215 i WSA w Gliwicach z dnia 15 grudnia 2016 r., I SA/Gl 644/16, LEX nr 2199503.

25 Pogląd ten odnaleźć można m.in. w wyrokach: WSA w Lublinie z dnia 25 października 2019 r., I SA/Lu 417/19, LEX nr 2738856 („,Przepis art. 40d ust. 3 u.d.p., przewidujący pięcioletni termin przedawnienia należności, biegnący od końca roku kalendarzowego, w którym należało je uiścić, samodzielnie reguluje jedynie długość i początek biegu terminu przedawnienia. Oznacza to, że art. 40d ust. 3 u.d.p. jako przepis szczególny wyłącza zastosowanie jedynie art. 70 § 1 Ordynacji podatkowej, który zawiera ten sam zakres regulacji. Przepisy ustawy o drogach publicznych nie odnoszą się natomiast do innych okoliczności mogących mieć znaczenie dla biegu terminu przedawnienia, jak przerwa lub zawieszenie jego biegu. W związku z tym do przedawnienia należności z tytułu opłaty dodatkowej odpowiednie zastosowanie będą miały przepisy art. $70 § 2-8$ Ordynacji podatkowej”), NSA z dnia 16 października 2019 r., I GSK 662/19, LEX nr 2730079, NSA z dnia 4 października 2019 r., I GSK 559/19, LEX nr 2726500, NSA z dnia 26 września 2019 r., I GSK 540/19, LEX nr 2740289, NSA z dnia 17 września 2019 r., I GSK 493/19, LEX nr 2729675, NSA z dnia 13 września 2019 r., I GSK 492/19, LEX nr 2719186, NSA z dnia 14 sierpnia 2019 r., I GSK 275/19, LEX nr 2705829, NSA z dnia 8 sierpnia 2019 r., I GSK 274/19, LEX nr 2718601, NSA z dnia 10 maja 2019 r., I GSK 42/19, LEX nr 2682043, WSA w Lublinie z dnia 5 kwietnia 2019 r., I SA/Lu 943/18, LEX nr 2714314, WSA w Gdańsku z dnia 20 marca 2018 r., I SA/Gd 82/18, LEX nr 2466429, WSA w Rzeszowie z dnia 2 sierpnia 2018 r., I SA/Rz 457/18, LEX nr 2535241. 
zgodne i które mogą być pomocne ustawodawcy przy zajmowaniu stanowiska w sprawie.

P. Zaborniak uważa, że opłata SPP, opłata ŚSPP i opłata dodatkowa nie podlegają przepisom Ordynacji podatkowej. Autor ten swoje stanowisko wywodzi z analizy definicji legalnej podatku i opłaty zawartej w art. 6 w zw. z art. 3 pkt 3 lit. c Ordynacji podatkowej i zauważa, że choć ww. opłaty są publicznoprawnymi, nieodpłatnymi, przymusowymi i bezzwrotnymi świadczeniami, to nie można pomijać okoliczności, że u.d.p. nie jest ustawą podatkową, a jest to równoprawny i konieczny warunek, aby do danego świadczenia zastosowanie znajdowała Ordynacja podatkowa. Ponadto nie wszystkie podmioty uprawnione do pobierania ww. opłat noszą cechy organu podatkowego. Nie bez znaczenia pozostaje również fakt, że wpływy z ww. opłat odprowadzane są na rachunek Krajowego Funduszu Drogowego. Zatem w zakresie nieuregulowanym w u.d.p. do opłaty SPP, opłaty ŚSPP i opłaty dodatkowej należy stosować przepisy Kodeksu postępowania administracyjnego ${ }^{26}$ i ustawy o postępowaniu egzekucyjnym w administracji ${ }^{27} 28$.

K. Sobieralski stoi na stanowisku, że „do rozstrzygania spraw dotyczących opłaty dodatkowej za parkowanie w strefie płatnego parkowania nie można stosować przepisów Ordynacji podatkowej. Autor ten wyprowadza z tego wniosek, że brak jest zatem możliwości przerwania i prolongowania biegu pięcioletniego terminu jej przedawnienia, nawet przez zastosowanie środka egzekucyjnego wymienionego w ustawie o postępowaniu egzekucyjnym $\mathrm{w}$ administracji. W konsekwencji wierzyciel oraz organ egzekucyjny muszą zdążyć dokonać czynności procesowych postępowania egzekucyjnego, zastosować środek lub środki egzekucyjne i wyegzekwować całą należność przed upływem tego okresu”29.

26 Ustawa z dnia 14 czerwca 1960 r. Kodeks postępowania administracyjnego (tekst jedn. Dz.U. z 2021 r. poz. 735).

27 Ustawa z dnia 17 czerwca 1966 r. o postępowaniu egzekucyjnym w administracji (tekst jedn. Dz.U. z 2020 r. poz. 1427).

28 P. Zaborniak [w:] W. Maciejko, P. Zaborniak, Ustawa o drogach publicznych. Komentarz, Lex/el. 2010, komentarz do art. 13.

29 K. Sobieralski, Dodatkowa opłata za parkowanie w strefie płatnego parkowania, „Nowe Zeszyty Samorządowe” 2009, nr 2, s. 39 i n. 
Autor niniejszego artykułu podziela poglądy P. Zaborniaka i K. Sobieralskiego, przy czym podnosi dodatkowo, że dobrą praktyką legislacyjną powinno być określanie wprost przez ustawodawcę, czy do danego świadczenia o charakterze opłatowym właściwa jest Ordynacja podatkowa (a jeśli nie, to powinna być wskazana właściwa ustawa). W razie braku takiego przepisu, jak widać na przykładzie analizowanych opłat, mogą wystąpić duże wątpliwości. Z drugiej strony brak takiego odesłania można interpretować na korzyść stanowiska o braku zastosowania Ordynacji podatkowej do o.SPP, o.ŚSPP i opłaty dodatkowej, a co za tym idzie, wydaje się, że należałoby stosować do nich przepisy ustawy o finansach publicznych $^{30}$ (przede wszystkim jej art. 60-67).

\section{Bibliografia:}

Rychter R.A., Ustawa o drogach publicznych. Komentarz, LEX/el. 2019, komentarz do art. 13.

Sobieralski K., Dodatkowa opłata za parkowanie w strefie płatnego parkowania, „Nowe Zeszyty Samorządowe” 2009, nr 2, s. 39-44.

Sobieralski K., Reklamacja należnych opłat dodatkowych za parkowanie, „Nowe Zeszyty Samorządowe” 2010, nr 4, s. 21-27.

Sobieralski K., Wierzyciel w postępowaniu egzekucyjnym w administracji opłaty dodatkowej za parkowanie pojazdów samochodowych na drogach publicznych $w$ strefie płatnego parkowania, „Nowe Zeszyty Samorządowe” 2008, nr 6, s. 40-44.

Sondej M.Z., Zastosowanie przepisów Ordynacji podatkowej względem przedawnienia opłaty dodatkowej za parkowanie w strefie płatnego parkowania, LEX/el. 2020.

Zaborniak P. [w:] W. Maciejko, P. Zaborniak, Ustawa o drogach publicznych. Komentarz, Lex/el. 2010, komentarz do art. 13.

30 Ustawa z dnia 27 sierpnia 2009 r. o finansach publicznych (tekst jedn. Dz.U. z 2021 r. poz. 305). 